\title{
A Trough System for Measuring Transmission of Tomato Ringspot Virus by Dagger Nematodes
}

\author{
W.L. Mountain \\ Pennsylvania Department of Agriculture, 2301 North Cameron Street, \\ Harrisburg, PA 17110
}

C.A. Powell

University of Florida, Institute of Food and Agricultural Sciences, Agricultural Research and Education Center, Box 248, Fort Pierce, FL 34954

L.B. Forer

Pennsylvania Department of Agriculture, 2301 North Cameron Street, Harrisburg, PA 17110

Additional index words. stem-pitting disease, plant growing technique

\begin{abstract}
A trough system was developed to study rates of plant virus transmission by plant parasitic nematodes. Perforated plumber's polyvinyl chloride pipe, $5 \mathrm{~cm}$ in diameter, was cut into $48-\mathrm{cm}$ lengths, split longitudinally, and fashioned into troughs to hold soil and common dandelion (Taraxacum officinale Webber) transplants. The first plant in each trough was infected with tomato ringspot virus (TmRSV), followed by 10 uninfected plants spaced at $4-\mathrm{cm}$ intervals. The soil contained a high concentration of Xiphinema rivesi (199 per $\left.100 \mathrm{~cm}^{3}\right)$, a low concentration $\left(16\right.$ per $\left.100 \mathrm{~cm}^{3}\right)$, or none. Plants were assayed biweekly for TmRSV. After 42 weeks, transmission rates between the low and high concentrations of nematodes were not significantly different. The subirrigated trough system provided excellent soil conditions for plant growth and sufficient nematode survival to detect virus transmission through 36 weeks.
\end{abstract}

Tomato ringspot virus (TmRSV) causes serious disease on diverse crops (Powell, 1984). The virus and its dagger nematode vector(s), Xiphinema americanum Cobb (Bonsi et al., 1984; Teliz et al., 1966) and $X$. rivesi (Forer et al., 1981), are widespread, occurring in the northeastern and central United States, California, British Columbia, and Ontario. The most serious TmRSV-induced disease, the prunus stempitting (PSP) (Smith et al., 1973) disease, is prevalent in peach [Prunus persica (L.) Batsch.] growing regions of the northeastern United States. The virus persists in orchards and vineyards in nematodes and alternate hosts, especially common dandelion (Miller, 1980; Mountain et al., 1983; Powell et al., 1982, 1984).

Soil fumigation has been used to reduce plant parasitic nematodes in soils and has successfully controlled PSP in nurseries (Powell et al., 1982). However, nematode control is not $100 \%$ effective, particularly in deep soils. The dagger nematode population levels that must be present for an orchard to be at risk to TmRSV-induced disease have not been determined. Information on this is-

Received for publication 20 Feb. 1992. Accepted for publication 23 July 1992. Agricultural Journal Series no R-01884. The cost of publishing this paper was defrayed in part by the payment of page charges. Under postal regulations, this paper therefore must be hereby marked advertisement solely to indicate this fact. sue greatly affects control strategies.

Studies of virus transmission by nematodes are traditionally performed by using small pots of vector-infested soil. However, maintaining ideal air : water ratios in small soil volumes, important for plant growth and nematode survival, is difficult. This problem is frequently compounded by surface irrigation. However, in the system introduced here, transmission studies can be maintained over an extended period by maximizing soil pore space and reducing fluctuations in air : water ratios and in evaporation from the soil surface. This system, termed the trough technique, was used to compare transmission rates of TmRSV to dandelion in soil containing low and high levels of $X$. rivesi.

A loam field soil (coarse-loamy, mixed, mesic, ultic hapludalfs) in southeastern Pennsylvania, adjacent to a vineyard and containing a high concentration of $X$. rivesi, was collected in 35-liter tubs, sown with sudan grass [Sorghum sundanense (Piper) Stapf], and maintained in the greenhouse. After 6 months, the soil was bait-tested with dandelion and cucumber (Cucumis sativus L. 'National Pickling') and found to be free of TmRSV.

Five-centimeter-diameter polyvinylchloride (PVC) pipe was cut into 48-cm lengths, and a narrow 3-cm strip was cut longitudinally and removed to form a trough (Fig. 1). Holes, $3 \mathrm{~mm}$ in diameter and $4 \mathrm{~cm}$ apart, were drilled in the bottom throughout the length of the trough for irrigation. Card- board, cut to fit the ends of the trough, was soaked in hot paraffin wax and affixed (solidified paraffin wax) at the ends to retain the soil. These level troughs were then placed in larger, 50-cm-long level troughs cut from 10-cm-diameter PVC sewer and drain pipe (Fig. 1). The ends were sealed as for the smaller troughs.

Xiphinema rivesi- infested soil from a greenhouse culture was passed through a 6mm-mesh screen to remove larger stones and debris. This screened soil served as the highnematode-level soil. Low-nematode-level soil was produced by steaming 9 parts high concentration soil and, after aerating for 1 day, mixing with 1 part unsteamed soil. After thoroughly mixing soils of each treatment, ten $100-\mathrm{cm}^{3}$ subsamples were taken from each treatment; the nematodes then were extracted by the wet sieve Baerman Funnel process and counted (Flegg and Hopper, 1970). The low nematode concentration was $16 \mathrm{X}$. rivesi per $100 \mathrm{~cm}^{3}$ of soil, and the high one was 199 per $100 \mathrm{~cm}^{3}$.

Four-week-old dandelion seedlings, the progeny of serologically confirmed (Clark and Adams, 1977) TmRSV-infected [TmRSV is seed transmitted in dandelion at rates up to

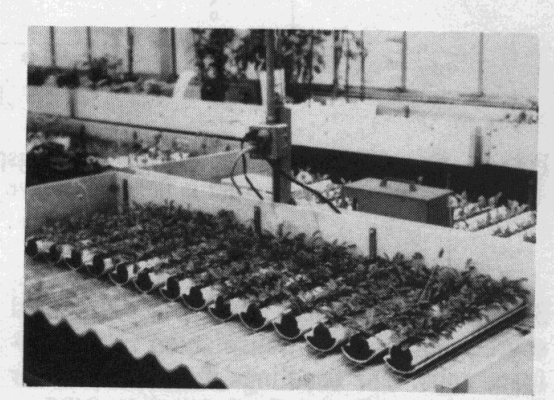

Fig. 1. Trough components in position for subirrigation.

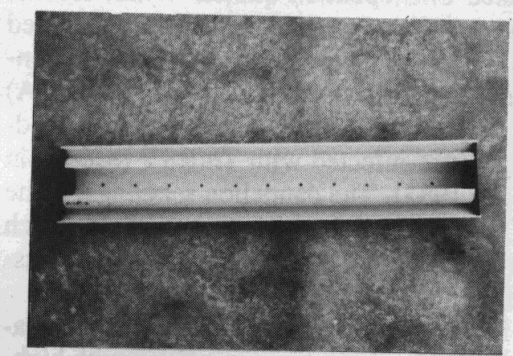

Fig. 2. Trough system on greenhouse bench before assembly.

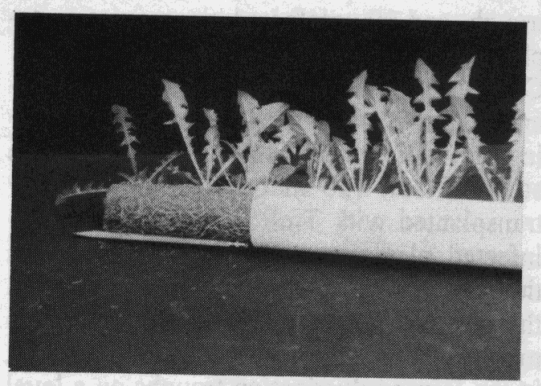

Fig. 3. Trough disassembled after 42 weeks. 
Table 1. Transmission of tomato ringspot virus by the nematode Xiphinema rivesi with the trough technique.

\begin{tabular}{lrr}
\hline \hline & \multicolumn{2}{c}{ Nematode concn } \\
\cline { 2 - 3 } Criterion & Low $^{z}$ & High $^{z}$ \\
\hline Mean no. plants infected per troughy & 8.2 & 9.4 \\
Mean no. weeks until first plant was infected & 7.2 & 7.2 \\
Mean no. weeks until last plant was infected & 23.6 & 25.8 \\
Mean rate of infection (no. plants/week from first & 0.56 & 0.58 \\
$\quad$ infection) & 0.36 & 0.38 \\
Mean rate of infection (no. plants/week from week 0) & & \\
\hline
\end{tabular}

${ }^{z}$ Low concentration $=16 X$. rivesi $/ 100 \mathrm{~cm}^{3}$ of soil. High concentration $=199 X$. rivesi $/ 100 \mathrm{~cm}^{3}$ of soil. None of the comparisons between high and low concentrations of nematodes was significantly different ( $t$ test, $P \leq 0.05)$.

yFrom five replications.

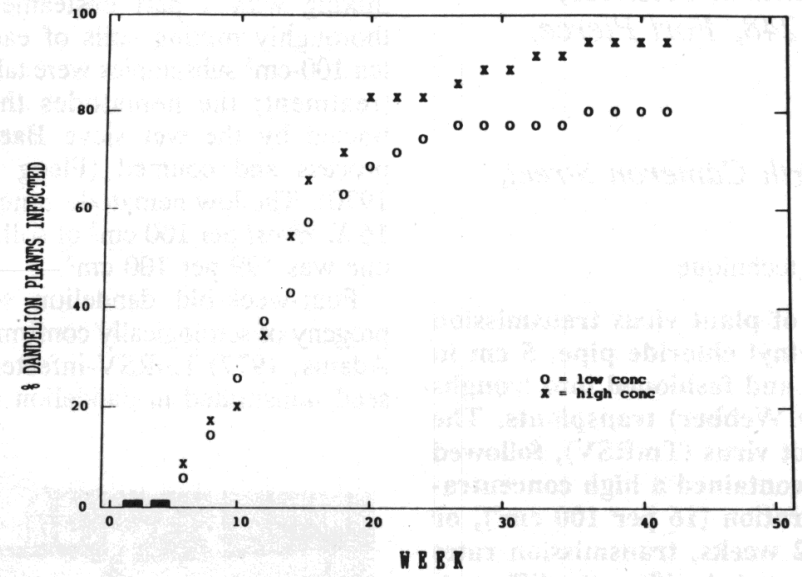

Fig. 4. Cumulative transmission of tomato ringspot virus to dandelion by Xiphinema rivesi using the trough technique. Each point is the sum of five replicates. $100 \%=50$ plants.

34\% (Mountain et al., 1983)] or uninfected source plants, were transplanted into styrofoam cups. The seedlings were assayed for TmRSV by grinding leaf tissue in $0.05 \mathrm{M}$ potassium phosphate buffer, $\mathrm{pH} 7.0$, and rubbing the sap onto Carborundum (320 grit)dusted Chenopodium quinoa Willd. leaves. Chenopodium quinoa plants that developed lesions were assayed for TmRSV by enzyme-linked immunosorbent assay (ELISA) to confirm that the original dandelion seedlings were infected with TmRSV (Mountain et al., 1983). The dandelion seedlings, some of which tested positive and some of which tested negative for TmRSV, were transplanted into troughs.

Five troughs were filled with low-nematode-level soil and five were filled with highnematode-level soil. For treatments with TmRSV-infected dandelions, one infected plant was transplanted at one end of each trough, and 10 uninfected plants were transplanted along the trough at $4-\mathrm{cm}$ intervals. Controls consisted of one trough each of lowand high-nematode-level treatments containing only uninfected plants and a trough with steamed soil (no nematodes) alternately transplanted with TmRSV-infected and uninfected plants as a "contact" control. A thermograph-sensing probe was centered in the soil column of an additional trough to monitor temperature. Filled troughs were set in the larger subirrigation troughs on a level bench in the greenhouse that was heated at
18C and cooled at 27C (Fig. 2). Troughs were bottom-irrigated once daily, or more often if needed to maintain desirable plant growth. Dandelion leaf samples (youngest leaves) were indexed biweekly on $C$. quinoa as previously described to determine if any uninfected leaf tissue became infected with TmRSV. Starting with the 5th week, troughs were fertilized weekly with $5 \mathrm{ml}$ of $20 \mathrm{~N}$ 8.8P-16.6K soluble fertilizer (2.5 g. liter $^{-1}$ ) through week 15 , and thereafter with $10 \mathrm{ml}$ of the fertilizer solution. After 42 weeks, troughs were disassembled (Fig. 3) and soil was assessed for surviving $X$. rivesi.

Pest control was carried out by rolling troughs onto their sides $\left(\approx 90^{\circ}\right)$ and spraying the foliage biweekly or more often, if needed. Pests encountered and pesticides used were: mites, decachlorobis-2,4-cyclopentadien-1-yl (dienochlor); whiteflies, (E,E)-2-propyhyl 3,7,11-trimethyl-2,4-dodecdienoate (kinoprene); and thrips, dimethyl[(dimethoxy phosphinothioyl)thio]butanedioate (malathion). Care was taken to prevent pesticides from contacting the soil. Dead and senescing leaves were periodically removed as an additional pest control measure.

Transmission of TmRSV was not significantly different (least significant difference) for the $X$. rivesi at low and high nematode levels (Table 1). In the low and high population treatments, $82 \%$ and $94 \%$ of the plants became infected, respectively, with TmRSV (Fig. 4). No TmRSV transmission was de- tected in the control troughs with nematodes but without a TmRSV-infected dandelion or in troughs without nematodes but with TmRSV-infected dandelions. With each treatment, TmRSV-infected leaves were first detected at 6 weeks; the mean of the five replicates was 7.2 weeks in troughs containing either low or high nematode concentrations. Transmission of the virus to previously uninfected dandelion plants in each treatment was last detected at 36 weeks, and the replicate mean was 23.6 and 24.6 weeks for the low and high nematode population treatments, respectively. Transmission rate differences from either the time of the first infection or from week 0 also were similar between treatments (Table 1). Fifty-five percent of all transmission was detected from weeks 10-16, when the transmission rate was exponential (Fig. 4). Eighty-six percent of 14 "skips" (plants not adjacent to infected plants becoming infected) occurred during this phase. One double skip occurred. Also, the most rapid plant growth was observed during this period.

At the 16th-week assay, the dandelion farthest from the original infected plant (but not all dandelions) in one trough of each treatment was infected. This result means the virus had spread $40 \mathrm{~cm}$ along the nematode/ plant complex in 16 weeks from week 0 , or in 10 weeks from the first newly infected plant. At week 18, virus was detected in all dandelions in one replicate trough of each treatment. In two of five troughs with 16 nematodes per $100 \mathrm{~cm}^{3}$ and in three of five troughs with 199 nematodes per $100 \mathrm{~cm}^{3}$ all dandelions were infected after 36 weeks.

By 42 weeks, when troughs were disassembled, the dandelion roots had ramified throughout the soil volume, forming a dense mat so that roots from individual plants were indistinguishable (Fig. 3). This root-soil column could be suspended vertically without pulling it apart. Soil was "spongy," which indicated a large pore space and desirable soil structure. The soil surface was loose and friable, contrasting with the encrusted surface and compacted nature of top-irrigated soils (Jones et al., 1969). The soil column temperature fluctuated from a mean daily low of $15 \mathrm{C}$ to a mean high of $25 \mathrm{C}$. Recorded soil temperatures ranged from 12 to $30 \mathrm{C}$.

Reducing dagger nematode concentration in soils may not control TmRSV-induced disease. Bonsi et al. (1984) found TmRSV was transmitted to dandelion in 10 of 20 pots into each of which a single viruliferous dagger nematode was placed. Our data do not answer the question of how many dagger nematodes per $100 \mathrm{~cm}^{3}$ of soil must be present for maximum transmission of TmRSV to orchard trees. However, the data do show that 16 nematodes per $100 \mathrm{~cm}^{3}$ of soil was as effective as 199 nematodes per $100 \mathrm{~cm}^{3}$ of soil, indicating a damage threshold for virus transmission at $<16$ nematodes per 100 $\mathrm{cm}^{3}$ of soil.

The pattern of cumulative transmission rates with this system resembled a typical plant growth curve (Fig. 4). As the dandelions were in the exponential growth phase, roots rap- 
idly occupied the soil mass, increasing the chances for nematode feeding and virus transmission. Roots of many plants may have extended to the trough ends. This phase of extensive root growth would also explain the many "skips" occurring at this time. Thus, the virus was probably transported throughout the trough by vegetative growth of the plant roots rather than nematode movement.

Several studies have focused on optimum survival conditions for dagger nematodes. Van Gundy et al. (1962) found greater survival of $X$. americanum at $21 \%$ soil oxygen than at lower concentrations, and when soil moisture was $11 \%$ compared with $25 \%$. Griffin and Barker (1966) found survival of $X$. americanum ideal at $20 \mathrm{C}$ on tomato (Lycopersicon esculentum Mill.) and at $24 \mathrm{C}$ on strawberry (Fragaria ×ananassa Duch.) if soil moisture was $>20 \%$ and $<90 \%$ field capacity. Lownsbery and Maggenti (1963) reported $X$. americanum survival optimum at 21C with low-amplitude moisture fluctuation. Schmitt (1973) also cited moisture fluctuation as detrimental, whereas Douthit and McGuire (1975) determined 22C the optimum for survival. Even though mean soil temperature in our study was $20 \mathrm{C}$, the mean daily extremes were 15 and $25 \mathrm{C}$, and 12 and $30 \mathrm{C}$ were recorded. This variation could have contributed to the decline in the nematode population. Growth rooms or growth chamber environments, as well as more frequent small-volume irrigations, would minimize temperature and moisture fluctuations for improved nematode survival.

The trough technique has several advantages over the standard nematode transmission efficiency assays that involve replicated single pots. First, conditions favorable to plant growth and nematode survival are more easily maintained. Subirrigation, an important component of the trough technique, results in maintaining macropores in the soil, producing spongy structure and loose, friable surface, contrasted with top-irrigated soils (Jones et al., 1969; Ponchillia, 1972). The macropores permitted drainage, which de- creased the chance for hypoxia following irrigation. In addition, the small exposed soil surface area reduced evaporation, which is important when working with small soil volumes because dagger nematodes are very sensitive to soil moisture fluctuation. A second advantage of the trough technique was its flexibility. Troughs can be fashioned to any length, diameter, and size of top opening to best fit experimental needs. Plant spacing and cultivar, nematode species and concentration, as well as virus isolate, can easily be varied. A third advantage was that various components of efficiency of nematode transmission of a virus can be analyzed. In addition to the percentage of plants that become infected, the rate of infection and the distance the virus spreads through the roots and from plant to plant by the nematodes can be measured.

In summary, the trough technique is useful for time-course studies of virus-nematode vector-host relationships that attempt to simulate a field condition. The same system should be amenable to studies on plant growth response to a variety of soil additives.

\section{Literature Cited}

Bonsi, C., R. Stouffer, and W. Mountain. 1984. Efficiency of transmission of tomato ringspot virus by Xiphinema americanum and Xiphinema rivesi. Phytopathology 73:626. (Abstr.)

Clark, M.F. and A.N. Adams. 1977. Characteristics of the microplate method of enzyme-linked immunosorbent assay for the detection of plant viruses. J. General Virol. 34:475-483.

Douthit, L.B. and J.M. McGuire. 1975. Some effects of temperature on Xiphinema americanum and infection of cucumber by tobacco ringspot virus. Phytopathology 65:134-138.

Flegg, J.J.M. and J. Hopper. 1970, Extraction of free-living stages from soil, p. 5-22. In: J.F. Southey (ed.). Laboratory methods for work with plant and soil nematodes. Tech. Bul. 2, Hindson and Andrew Reid Ltd., Newcastle upon Tyne, U.K.

Forer, L.B., N.S. Hill, and C.A. Powell. 1981. Xiphinema rivesi, a new tomato ringspot virus vector. Phytopathology 71:874. (Abstr.)
Griffin, G.D. and K.R. Barker. 1966. Effects of soil temperature and moisture on the survival and activity of Xiphinema americanum. Proc. Helminthol. Soc. Wash. 33:126-130.

Jones, F.G.W., D.W. Larbey, and D.M. Parrott. 1969. The influence of soil structure and moisture on nematodes, especially Xiphinema, Longidorus, Trichodorus, and Heterodera spp. Soil Biol. 1:153-165.

Lownsbery, B.F. and A.R. Maggenti. 1963. Some effects of soil temperature and soil moisture on population levels of Xiphinema americanum. Phytopathology 53:667-668.

Miller, P.M. 1980. Reproduction and survival of Xiphinema americanum on selected woody plants, crops and weeds. Plant Dis. 64:174175.

Mountain, W.L., C.A. Powell, L.B. Forer, and R.F. Stouffer. 1983. Transmission of tomato ringspot virus from dandelion via seed and dagger nematodes. Plant Dis. 67:867-868.

Ponchillia, P.E. 1972. Xiphinema americanum as affected by soil organic matter and porosity. J. Nematol. 4:189-193.

Powell, C.A. 1984. Comparison of enzyme-linked immunosorbent assay procedures for detection of tomato ringspot virus in woody and herbaceous hosts. Plant Dis. 68:908-909.

Powell, C.A., L.B. Forer, and R.F. Stouffer. 1982. Reservoirs of tomato ringspot virus in fruit orchards. Plant Dis. 66:583-584.

Powell, C.A., W.L. Mountain, T. Dick, L.B. Forer, M.A. Derr, L.D. Lathrop, and R.F. Stouffer. 1984. Distribution of tomato ringspot virus in dandelion in Pennsylvania. Plant Dis. 68:796-798.

Schmitt, D.P. 1973. Soil property influences on Xiphinema americanum populations as related to maturity of loess-derived soils. J. Nematol. 5:234-240.

Smith, S.H., R.F. Stouffer, and D.M. Soulen. 1973. Induction of stem pitting in peaches by mechanical inoculation with tomato ringspot virus. Phytopathology 63:1404-1406.

Teliz, D., R.G. Grogan, and B.F. Lownsbery. 1966. Transmission of tomato ringspot, peach yellow bud mosaic, and grape yellow vein viruses by Xiphinema americanum. Phytopathology 56:658-663.

Van Gundy, S.D., L.H. Stolzy, T.E. Szuszkiewicz, and R.L. Rackham. 1962. Influence of oxygen supply on survival of plant parasitic nematodes in soil. Phytopathology 52:628-632. 